\title{
FAKTOR-FAKTOR YANG MEMPENGARUHI MINAT CALON PEMBELI APARTEMEN MENENGAH - BAWAH DI SURABAYA
}

\author{
Tommy Prayogo ${ }^{1}$, Timoticin Kwanda², Jani Rahardjo ${ }^{3}$
}

\begin{abstract}
ABSTRAK: Saat ini masyarakat Surabaya sudah tidak asing dengan adanya pembangunan apartemen. Dikala melimpahnya jumlah suplai unit apartemen, terjadi kelesuan dalam segi penjualan yang disebabkan oleh tekanan ekonomi Indonesia. Maka dari itu pengembang membutuhkan strategi pemasaran yang tepat disaat perlambatan laju perekonomian Indonesia. Kunci dari keberhasilan penjualan adalah dengan memenuhi apa yang diharapkan dan diinginkan oleh calon pembeli. Penelitian ini mengeksplorasi 6 faktor yang dirasa berpengaruh terhadap minat calon pembeli apartemen menengah - bawah di Surabaya yaitu faktor harga, lokasi, fisik bangunan, fasilitas, lingkungan dan promosi. Hasil penelitian ini menyatakan bahwa hanya faktor harga dan faktor lokasi yang berpengaruh signifikan terhadap minat calon pembeli apartemen menengah - bawah di Surabaya. Faktor harga merupakan faktor yang paling mempengaruhi minat calon pembeli apartemen menengah bawah di Surabaya.
\end{abstract}

Kata kunci : harga, lokasi, fisik bangunan, fasilitas, lingkungan, promosi, minat beli, apartemen menengah - bawah

ABSTRACT : Recently, people in Surabaya have been accustomed to the construction of new apartments. While the supply of apartment units plentyful, the sales performance of apartment units decreased. Therefore developers need a proper marketing strategy while the rate of the Indonesian economy is declining. The key to success sales performance are to fulfill what is expected and desired by buyers. This research investigates 6 factors that effect prospective buyers intention to buy middle-lower apartments in Surabaya. This study explored where price, location, physical building, facility, environment and promotion are considered as most influential factors. Only price factor and location have significant relationship with buying. The price factor is the main factor that affect prospective buyer intention to buy middle-lower apartements in Surabaya.

Keywords: price, location, physical buildings, facility, environment, promotion, buying intention, middle - lower apartement

\section{PENDAHULUAN}

Di Kota Surabaya, pertumbuhan penduduk menjadi sebuah masalah yang terkait dengan penyediaan pemukiman. Akibatnya harga lahan di Kota Surabaya melambung tinggi akibat permintaan yang besar. Tuntutan inilah yang membuat gencarnya pembangunan secara vertikal di Surabaya dibandingkan dengan pembangunan kawasan perumahan. Dikala melimpahnya jumlah suplai unit apartemen, terjadi kelesuan dalam segi penjualan yang disebabkan oleh tekanan ekonomi Indonesia. Maka dari itu pengembang membutuhkan strategi yang baik untuk tetap dapat memasarkan produknya di tengah perlambatan ekonomi Indonesia. Dengan mengetahui serta berusaha memenuhi apa yang diinginkan oleh calon

\footnotetext{
${ }^{1}$ Mahasiswa Program Studi Magister Teknik Sipil Universitas Kristen Petra, officialhong@gmail.com

${ }^{2}$ Dosen Program Studi Magister Teknik Sipil Universitas Kristen Petra, cornelia@petra.ac.id

${ }^{3}$ Dosen Program Studi Magister Teknik Sipil Universitas Kristen Petra, jani@petra.ac.id
} 
pembeli, diharapkan mampu menarik minat calon pembeli apartemen sehingga keberhasilan penjualan dapat tercapai. Faktor harga menjadi pertimbangan calon pembeli ketika ingin membeli apartemen (Kamal \& Pramanik, 2015). Semakin terjangkau harga yang ditawarkan mampu menarik minat calon pembeli apartemen. Faktor lokasi, fisik bangunan dan fasilitas berpengaruh terhadap minat beli apartemen (Kamal \& Pramanik, 2015). Lokasi yang strategis diinginkan oleh calon pembeli apartemen. Faktor lingkungan juga dipertimbangkan oleh calon pembeli sebelum membeli hunian seperti tingkat kebisingan di wilayah sekitar hunian, tingkat kemacetan lalu-lintas di wilayah sekitar hunian dan tingkat keamanan wilayah sekitar hunian (Dewri, Amin, Sen, \& Faridi, 20142). Maka dari itu lingkungan menjadi daya tarik tersendiri bagi calon pembeli apartemen. Selain itu faktor promosi juga dipertimbangkan oleh calon pembeli ketika ingin membeli apartemen (Islam, 2012). Pemenuhan akan kebutuhan pertimbangan - pertimbangan tersebut dirasa dapat menarik minat calon pembeli apartemen. Melihat banyaknya faktor yang dipertimbangkan oleh calon pembeli maka dari itu penulis ingin mengkaji lebih dalam lagi apakah faktor harga, lokasi, fisik bangunan, fasilitas, lingkungan dan promosi berpengaruh terhadap minat calon pembeli pada apartemen menengah - bawah yang berlokasi di Surabaya.

\section{TINJAUAN PUSTAKA}

\subsection{Minat Pembelian}

Dalam usaha menarik atau menumbuhkan minat beli konsumen, pemasar harus terlebih dahulu memahami apa yang diharapkan dan diinginkan oleh konsumen sebelum membeli suatu produk. Menurut Kinnear \& Taylor (2003), minat beli merupakan bagian dari komponen perilaku konsumen dalam sikap mengkonsumsi, kecenderungan responden untuk bertindak sebelum keputusan membeli benar-benar dilaksanakan. Sedangkan menurut Kotler \& Keller (2009), menyatakan bahwa minat beli konsumen merupakan sebuah perilaku konsumen dimana konsumen mempunyai keinginan dalam memilih, menggunakan, dan mengkonsumsi atau bahkan menginginkan suatu produk yang ditawarkan. Dapat disimpulkan bahwa minat beli adalah sebuah perilaku yang timbul dari diri seseorang dalam menginginkan suatu produk yang ditawarkan dimana keinginan tersebut muncul sebelum melakukan keputusan pembelian benar-benar terjadi. Minat beli konsumen merupakan masalah yang sangat kompleks, namun harus tetap menjadi perhatian pemasar. Minat konsumen untuk membeli dapat muncul sebagai akibat adanya rangsangan (stimulus) yang ditawarkan oleh perusahaan. Masing-masing stimulus tersebut dirancang untuk menghasilkan tindakan pembelian konsumen.

\subsection{Apartemen Kelas Menengah - Bawah Berdasarkan Harga dan Biaya Pemeliharaan}

Berdasarkan golongan sosial pada pembangunan apartemen dibagi menjadi empat jenis antara lain apartemen sederhana, apartemen menengah, apartemen mewah, dan apartemen super mewah. Yang membedakan keempat tipe diatas adalah fasilitas yang terdapat dalam apartemen tersebut. Semakin lengkap fasilitas dalam sebuah apartemen, maka semakin mewah apartemen tersebut. Pemilihan bahan bangunan dan sistem apartemen juga berpengaruh. Semakin baik kualitas material dan semakin banyak pelayanannya, semakin mewah apartemen tersebut (Savitri \& Ignatius \& Budiharjo \& Anwar \& Rahwidyasa, 2007). Dari segi harga apartemen, berdasarkan survei properti kuartal III/2016 oleh Jones Lang Lasalle, rata-rata penjualan apartemen segmen atas berada di kisaran harga $R p 25$ juta - Rp $38 \mathrm{juta} / \mathrm{m}^{2}$, sedangkan segmen menengah berada di kisaran harga Rp 18 juta - Rp $24 \mathrm{juta} / \mathrm{m}^{2}$ dan segmen ke bawah dengan kisaran harga Rp 9 juta- Rp 17 juta/m² (Widarti, 2016). Harga apartemen kelas menengah ke bawah di Surabaya yaitu mulai dari harga 300 juta - 700 juta rupiah (Colliers International Indonesia, 2017). Menurut Khoiruddin (2010), dari segi biaya 
pemeliharaan ada 2 jenis biaya pemeliharaan pada apartemen yaitu biaya servis (pemeliharaan gedung) dan biaya sinking fund (perawatan gedung).

\subsection{Faktor-Faktor yang Mempengaruhi Minat Beli Apartemen}

Perlu untuk mengetahui faktor-faktor apa saja yang dipertimbangkan oleh calon pembeli dalam memilih apartemen yang diinginkan. Dengan memenuhi apa yang diharapkan oleh calon pembeli apartemen diharapkan dapat meningkatkan minat beli calon pembeli terhadap apartemen yang ditawarkan oleh pengembang. Berikut adalah faktor - faktor yang dirasa dapat mempengaruhi minat calon pembeli apartemen.

1. Harga

Menurut Kamal \& Pramanik (2015), selain harga yang terjangkau, ketersediaan pinjaman dari bank dan cicilan yang terjangkau merupakan faktor dipertimbangkan dalam memilih apartemen. Harga yang terjangkau menjadi pertimbangan konsumen sebelum membeli apartemen (Mollah \& Pasha, 2009). Menurut Cahyani, Ilhamdaniah, \& Indra (2012), harga merupakan salah satu preferensi dalam pembelian apartemen di Kota Bandung. Dari segi biaya pemeliharaan di dalam apartemen menurut Khoiruddin (2010), ada sejumlah biaya yang harus dibayarkan untuk pemeliharaan gedung baik biaya servis maupun biaya sinking fund. Keterjangkauan akan biaya-biaya tersebut dirasa dapat menarik minat calon pembeli apartemen.

2. Lokasi

Apartemen biasanya dihuni oleh masyarakat yang memiliki mobilitas yang tinggi. Masyarakat pada umumnya menginginkan lokasi apartemen yang memiliki akses yang cepat dan mudah. Lokasi apartemen yang strategis adalah impian banyak orang karena letaknya yang dekat dengan berbagai fasilitas umum, mudah dijangkau bahkan apabila ingin berpergian ke suatu tempat jaraknya bisa menjadi lebih dekat dan menghemat waktu. Menurut Mollah \& Pasha (2009), Lokasi yang strategis mampu menarik minat beli konsumen apartemen. Beberapa alasan terkait lokasi yang menjadi pertimbangan konsumen dalam membeli apartemen adalah dekat dengan tempat kerja, dekat dengan fasilitas pendidikan, dan ketersediaan sarana transportasi. Menurut Cahyani, Ilhamdiah, \& Indra (2012), faktor-faktor utama pertimbangan masyarakat dalam membeli apartemen di Kota Bandung terkait lokasi adalah kedekatan dengan tempat kerja, kemudahan akses tol, dan lokasi apartemen berada di tengah kota. Menurut Kamal \& Pramanik (2015), dekat dengan tempat kerja, dengan dengan sekolah, dan tersedianya sarana transportasi di sekitar apartemen menjadi pertimbangan dalam memilih apartemen di Kota Dhaka, Bangladesh. Lokasi yang strategis dirasa mampu menarik minat calon pembeli apartemen. Menurut Kamal \& Pramanik (2015), lokasi berpengaruh terhadap minat beli apartemen.

3. Fisik Bangunan

Faktor kualitas fisik bangunan juga dipertimbangkan konsumen dalam memilih hunian apartemen. Luas ukuran merupakan hal yang pertimbangan konsumen. Calon pembeli pada umumnya akan mempertimbangkan dan membandingkan luasan unit apartemen yang ditawarkan oleh para pengembang apartemen. Ragam jenis unit apartemen juga dipertimbangkan oleh calon pembeli. Calon pembeli akan menyesesuaikan kebutuhan ruang dengan sesuai kebutuhannya (Manivannan \& Somasundaram, 2014). Selain luasan unit dan ragam jenis unit apartemen, sistem drainase yang baik pada apartemen dalam artian tidak terjadi banjir juga patut dipertimbangkan oleh calon pembeli apartemen. Pemenuhan kebutuhan akan pertimbangan - pertimbangan tersebut dirasa mampu menarik minat calon pembeli apartemen. Fisik bangunan berpengaruh terhadap minat beli apartemen di Kota Dhaka, Bangladesh (Kamal \& Pramanik, 2015).

4. Fasilitas

Fasilitas yang lengkap juga menjadi salah satu daya tarik yang ditawarkan apartemen. Fasilitas standar yang biasanya diberikan pengelola apartemen, di antaranya kolam renang, pusat kebugaran, tempat spa atau sauna, tempat parkir kendaraan yang memadai dan lain sebagainya. Fasilitas keamanan (CCTV 24 jam) menjadi pertimbangan konsumen 
sebelum membeli apartemen (Mollah \& Pasha, 2009). Menurut Kamal \& Pramanik (2015), fasilitas berpengaruh terhadap minat calon pembeli apartemen. Calon pembeli lebih tertarik membeli apartemen yang memiliki fasilitas komersil (minimarket, salon, restaurant atau kafe), taman bermain untuk anak-anak, ketersediaan generator listrik ketika listrik padam, kolam renang, fitness center, ketersedian tempat parkir, dan ketersediaan lift. Semakin lengkap fasilitas yang ditawarkan dirasa dapat menarik minat calon pembeli apartemen.

5. Lingkungan

Menurut Dewri, Amin, Sen, \& Faridi (2012), faktor kualitas lingkungan juga dipertimbangkan oleh calon pembeli dalam memilih sebuah real estate. Kualitas lingkungan meliputi tingkat kebisingan di wilayah sekitar hunian, tingkat kemacetan lalulintas di wilayah sekitar hunian dan tingkat keamanan wilayah sekitar hunian. Tingkat keamanan wilayah sekitar pada hunian yang dimaksud adalah bebas dari kejahatan dan pelanggaran sosial. Terdapatnya pemandangan (view) yang indah menjadi faktor yang dipertimbangkan calon pembeli ketika ingin membeli apartemen (Manivannan \& Somasundaram, 2014). Pemenuhan kebutuhan akan hal tersebut dirasa mampu menarik minat calon pembeli apartemen. Namun hasil penelitian yang dilakukan oleh Kamal \& Pramanik (2015) menyatakan bahwa faktor lingkungan tidak berpengaruh signifikan terhadap minat pembelian apartemen di Kota Dhaka, Bangladesh.

6. Promosi

Penawaran - penawaran yang menarik dari pengembang dirasa dapat mempengaruhi minat beli konsumen sehingga dapat meningkatkan keberhasilan penjualan unit apartemen. Menurut Islam (2012), faktor promosi seperti iklan, reputasi nama pengembang, dan opini dari ahli properti (broker/agen properti) merupakan hal-hal yang diperhatikan calon pembeli ketika akan membeli suatu real estat. Hal-hal tersebut dirasa mampu menarik minat calon pembeli apartemen. Namun menurut Kamal \& Pramanik (2015), faktor promosi dinyatakan tidak berpengaruh signifikan terhadap minat pembelian apartemen di Kota Dhaka, Bangladesh.

\section{METODOLOGI PENELITIAN}

Teknik pengambilan sampel menggunakan teknik non-probability sampling, yaitu dengan purposive sampling. Penelitian ini dilakukan dengan menyebarkan kuesioner kepada calon pembeli apartemen menengah - bawah di Surabaya dimana harga apartemen menengah bawah dibatasi pada harga $\mathrm{Rp} 9 \mathrm{juta}-\mathrm{Rp} 17 \mathrm{juta} / \mathrm{m}^{2}$. Data yang didapatkan dari hasil kuesioner online akan dianalisa dengan bantuan program SPSS for Macintosh Version 24 berupa analisa deskriptif dan frekuensi jawaban responden.

\section{ANALISIS DAN PEMBAHASAN}

\subsection{Gambaran Umum Obyek Penelitian}

Penelitian yang akan dilakukan adalah mengenai faktor - faktor yang mempengaruhi minat calon pembeli apartemen menengah - bawah di Surabaya. Objek pada penelitian yang dilakukan adalah responden calon pembeli apartemen menengah - bawah di Surabaya. Selama pengumpulan data dilakukan, peneliti telah berhasil mendapatkan sebanyak 72 kuesioner. Dimana hanya 53 responden yang dapat mewakili untuk dapat dipakai dalam penelitian ini.

\subsection{Hasil Uji Validitas Kuesioner}

Uji validitas instrumen dilakukan untuk menunjukan keabsahan dari instrumen yang akan dipakai pada penelitian. Validitas adalah suatu ukuran yang menunjukkan tingkat kevalidan dan kesahihan suatu instrumen (Arikunto, 2006). Langkah dalam menguji validitas butir 
pertanyaan pada kuesioner yaitu mencari nilai corrected Item-Total correlation. Setiap pernyataan dinyatakan valid apabila corrected item total correlation yang dihasilkan di atas $\mathrm{r}$ tabel, yaitu sebesar 0,270 . Berdasarkan pengujian yang telah dilakukan dapat diketahui bahwa semua indikator memiliki nilai corrected item-total correlation $>0,270$. Maka dapat disimpulkan bahwa kuesioner yang digunakan telah valid dan mampu mengukur tiap variabel yang digunakan dalam penelitian ini.

\subsection{Hasil Uji Reliabilitas Kuesioner}

Instrumen juga harus memenuhi standar reliabilitas. Suatu instrumen dikatakan reliabel jika dapat dipercaya untuk mengumpulkan data penelitian. Menurut Arikunto (2006), reliabilitas menunjukan pada suatu pengertian bahwa suatu instrumen cukup dapat dipercaya untuk digunakan sebagai alat pengumpul data karena instrumen tersebut sudah cukup baik. Jika nilai cronbach alpha yang dinilai lebih besar dari 0,6, maka item-item yang digunakan dalam kuesioner dapat dinyatakan memiliki tingat reliabilitas yang kuat. Hasil pengujian yang tekah dilakukan menunjukkan nilai cronbach alpha lebih dari 0,6. Hal ini berarti variabel pada kuesioner reliabel.

\subsection{Hasil Analisa Deskriptif Faktor yang Mempengaruhi Minat Calon Pembeli Apartemen Menengah - Bawah di Surabaya}

Dari keenam faktor yaitu faktor harga (X1), lokasi (X2), fisik bangunan (X3), fasilitas (X4), lingkungan (X5) dan promosi (X6), didapatkan nilai rata-rata faktor harga sebesar 4,36. Kemudian diikuti oleh faktor lokasi dengan nilai rata-rata sebesar 4,04, faktor fisik bangunan dengan nilai rata-rata sebesar 4,42, faktor fasilitas dengan nilai rata-rata sebesar 4,11, faktor lingkungan dengan nilai rata-rata sebesar 4,36 dan faktor yang terakhir adalah faktor promosi memiliki nilai rata-rata sebesar 4,00. Hasil nilai - nilai tersebut yang nantinya akan digunakan dalam model regresi.

\subsection{Pengujian Hipotesis}

Untuk menguji hipotesis dalam penelitian ini mengenai pengaruh faktor harga, lokasi, fisik bangunan, fasilitas, lingkungan dan promosi terhadap minat calon pembeli apartemen menengah - bawah di Surabaya. Maka digunakan analisa regresi linier berganda baik melalui uji silmultan / secara bersama maupun uji parsial / secara individu untuk menjawab hipotesis penelitian ini.

\subsubsection{Analisa Regresi Linier Berganda}

Adapun maksud dari hasil persamaan pada penelitian ini. Dari koefisien analisa regresi linier berganda didapatkan model regresi sebagai berikut:

Minat Pembelian $=\beta_{\text {hrg }}$ Harga $+\beta_{\text {lok }}$ Lokasi $+\beta_{\text {fis }}$ FisikBangunan $+\beta_{\text {fas Fasilitas }}+\beta_{\text {lin }}$ Lingkungan $+\beta_{\text {pro Promosi }+\epsilon}$

Minat Pembelian = 8.946 Harga + 6.209 Lokasi + 1.462 FisikBangunan + 5.957 Fasilitas 4.910 Lingkungan +0.023 Promosi $+€$

1. Diperoleh koefisien regresi variabel harga $\left(\beta_{\mathrm{hrg}}\right)$ sebesar 8.946 , artinya apabila harga yang terjangkau, ketersediaan fasilitas kredit, skema cicilan yang terjangkau dan biaya pemeliharaan yang terjangkau ditingkatkan 1 satuan, maka minat calon pembeli apartemen menengah - bawah di Surabaya akan mengalami kenaikan yang paling besar yaitu sebesar 8.946 satuan. Koefisien bernilai positif artinya ada hubungan searah antara harga dengan minat beli apartemen menengah - bawah di Surabaya. 
2. Koefisien regresi variabel lokasi ( $\beta_{\text {lok }}$ ) sebesar 6.209 , artinya apabila lokasi semakin dengan tempat kerja, dekat dengan fasilitas, akses tol yang mudah dan ketersediaan sarana transportasi ditingkatkan 1 satuan, maka minat calon pembeli apartemen menengah bawah di Surabaya mengalami kenaikan yang berarti yaitu sebesar 6.209 satuan. Koefisien bernilai positif artinya ada hubungan searah antara lokasi dengan minat beli apartemen menengah - bawah di Surabaya.

3. Koefisien regresi variabel fisik bangunan $\left(\beta_{\text {fis }}\right)$ sebesar 1.462 , artinya apabila luas ukuran maupun ragam jenis unit apatemen serta terdapat sistem drainase yang baik (tidak banjir) ditingkatkan 1 satuan, maka minat calon pembeli apartemen menengah - bawah di Surabaya mengalami kenaikan sebesar 1.462 satuan. Koefisien bernilai positif artinya ada hubungan searah antara fisik bangunan dengan minat beli apartemen menengah - bawah di Surabaya.

4. Koefisien regresi variabel fasilitas $\left(\beta_{\mathrm{fas}}\right)$ sebesar 5.957 , artinya apabila fasilitas seperti tersedianya jumlah parkir dan lift yang memadai, tersedianya tempat bermain anak, fitness centre, kolam renang, area komersil di bawah apartemen dan sistem keamanan CCTV ditingkatkan 1 satuan, maka minat calon pembeli apartemen menengah - bawah di Surabaya mengalami kenaikan yang berarti yaitu sebesar 5.957 satuan. Koefisien bernilai positif artinya ada hubungan searah antara fasilitas dengan minat beli apartemen menengah - bawah di Surabaya.

5. Koefisien regresi variabel lingkungan $\left(\beta_{\text {lin }}\right)$ sebesar -4.910 , artinya apabila lingkungan (semakin bising, macet dan tidak aman pada lingkungan disekitar apartemen) ditingkatkan 1 satuan, maka minat calon pembeli apartemen menengah - bawah di Surabaya mengalami penurunan yaitu sebesar 4.190 satuan. Koefisien bernilai negatif artinya hubungan antara lingkungan dengan minat beli apartemen menengah - bawah di Surabaya berbanding terbalik.

6. Koefisien regresi variabel promosi $\left(\beta_{\text {pro }}\right)$ sebesar 0.023 , artinya apabila promosi melalui iklan, reputasi nama pengembang serta opini dari para ahli properti ditingkatkan 1 satuan, maka minat calon pembeli apartemen menengah - bawah di Surabaya mengalami kenaikan yaitu sebesar 0.023 satuan. Koefisien bernilai positif artinya ada hubungan searah antara promosi dengan minat beli apartemen menengah - bawah di Surabaya.

\subsubsection{Hasil Pengujian Simultan / Secara Bersama}

Didapatkan hasil nilai $F_{\text {hitung }}$ adalah sebesar 220.300 dengan tingkat signifikasi uji sebesar 0.000. Sedangkan $F_{\text {tabel }}$ pada tingkat kepercayaan 95\% adalah sebesar 2.154. Dengan demikian $F_{\text {hitung }}>F_{\text {tabel }}(220.300>2.41)$. Tingkat signifikan juga lebih kecil dari $0.05(0.00<$ 0.05). Dari hasil uji $F$ dalam penelitian ini, kesimpulan yang didapat adalah minimal ada satu variabel dependen yang berpengaruh signifikan terhadap minat calon pembeli apartemen menengah - bawah di Surabaya. Untuk mengetahui variabel apa saja yang berpengaruh signifikan tersebut maka dilanjutkan dengan melakukan uji secara parsial / secara individu (ttest).

\subsubsection{Hasil Pengujian Parsial / Secara Individu}

1. Berdasarkan hasil dari uji parsial (t-test) pada Tabel 1 menunjukan bahwa nilai hitung $t_{\text {hitung }}$ untuk variabel harga $\left(X_{1}\right)$ adalah sebesar 2,109 dengan tingkat signifikansi sebesar 0,040. Nilai $t_{\text {tabel }}$ yang didapat sebesar 2,012 . Karena nilai $t_{\text {hitung }}>t_{\text {tabel }}(2,109>2,012)$ dan tingkat signifikansi lebih kecil dari $0,05(0,040<0,05)$ maka $\mathrm{H}_{0}$ ditolak. Dengan demikian dapat disimpulkan bahwa harga berpengaruh positif signifikan terhadap minat calon pembeli apartemen menengah - bawah di Surabaya.

2. Nilai hitung $t_{\text {hitung }}$ untuk variabel lokasi $\left(X_{2}\right)$ adalah sebesar 2,134 dengan tingkat signifikansi sebesar 0,038 . Nilai $t_{\text {tabel }}$ yang didapat sebesar 2,012 . Karena nilai $t_{\text {hitung }}>t_{\text {tabel }}(2,134>$ $2,012)$ dan tingkat signifikansi lebih kecil dari $0,05(0,038<0,05)$ maka $_{0}$ ditolak. Dengan 
demikian dapat disimpulkan bahwa lokasi berpengaruh positif signifikan terhadap minat calon pembeli apartemen menengah - bawah di Surabaya.

3. Nilai hitung $t_{\text {hitung }}$ untuk variabel fisik bangunan $\left(X_{3}\right)$ adalah sebesar 0,347 dengan tingkat signifikansi sebesar 0,730. Nilai $t_{\text {tabel }}$ yang didapat sebesar 2,012 . Karena nilai $t_{\text {hitung }}<t_{\text {tabel }}$ $(0,347<2,012)$ dan tingkat signifikansi lebih besar dari $0,05(0,730>0,05)$ maka gagal tolak $\mathrm{H}_{0}$. Dengan demikian dapat disimpulkan bahwa fisik bangunan tidak berpengaruh signifikan terhadap minat calon pembeli apartemen menengah - bawah di Surabaya.

4. Nilai hitung $t_{\text {hitung }}$ untuk variabel fasilitas $\left(\mathrm{X}_{4}\right)$ adalah sebesar 1,403 dengan tingkat signifikansi sebesar 0,167 . Nilai $t_{\text {tabel }}$ yang didapat sebesar 2,012 . Karena nilai $t_{\text {hitung }}<t_{\text {tabel }}(1,403<$ $2,012)$ dan tingkat signifikansi lebih besar dari $0,05(0,167>0,05)$ maka gagal tolak $\mathrm{H}_{0}$. Dengan demikian dapat disimpulkan bahwa fasilitas tidak berpengaruh signifikan terhadap minat calon pembeli apartemen menengah - bawah di Surabaya.

5. Nilai hitung $t_{\text {hitung }}$ untuk variabel lingkungan $\left(X_{5}\right)$ adalah sebesar $-0,818$ dengan tingkat signifikansi sebesar 0,417 . Nilai $t_{\text {tabel }}$ yang didapat sebesar 2,012 . Karena nilai $t_{\text {hitung }}<t_{\text {tabel }}$ $(-0,818<2,012)$ dan tingkat signifikansi lebih besar dari $0,05(0,417>0,05)$ maka gagal tolak $\mathrm{H}_{0}$. Dengan demikian dapat disimpulkan bahwa lingkungan tidak berpengaruh signifikan terhadap minat calon pembeli apartemen menengah - bawah di Surabaya.

6. Nilai hitung $t_{\text {hitung }}$ untuk variabel promosi $\left(X_{6}\right)$ adalah sebesar 0,006 dengan tingkat signifikansi sebesar 0,995. Nilai $t_{\text {tabel }}$ yang didapat sebesar 2,012 . Karena nilai $t_{\text {hitung }}<t_{\text {tabel }}$ $(0,006<2,012)$ dan tingkat signifikansi lebih besar dari $0,05(0,995>0,05)$ maka gagal tolak $\mathrm{H}_{0}$. Dengan demikian dapat disimpulkan bahwa promosi tidak berpengaruh signifikan terhadap minat calon pembeli apartemen menengah - bawah di Surabaya.

Tabel 1. Hasil Uji Pengujian Parsial

\begin{tabular}{|c|c|c|c|}
\hline \multirow{2}{*}{ Model } & Unstandardized Coefficients & \multirow{2}{*}{ t } & Sig. \\
\cline { 2 - 3 } & 8.946 & 2.109 & .040 \\
\hline Hrg & 6.209 & 2.134 & .038 \\
\hline Lok & 1.462 & .347 & .730 \\
\hline Fis & 5.987 & 1.403 & .167 \\
\hline Fas & -4.910 & -.818 & .417 \\
\hline Lin & .023 & .006 & .995 \\
\hline Pro & &
\end{tabular}

\subsubsection{Hasil Uji Asumsi Klasik}

Dari hasil pengujian asumsi klasik terhadap nilai residual dalam model regresi ini, tidak ditemukan adanya penyimpangan terhadap nilai residual. Dengan demikian model regresi pada penelitian ini dikatakan layak karena telah lolos uji normalitas, uji homoskedastisitas, dan uji autokorelasi.

\section{KESIMPULAN}

Berdasarkan hasil pengolahan data dalam penelitian ini dapat ditarik kesimpulan sebagai berikut :

1. Faktor - faktor yang mempengaruhi minat calon pembeli apartemen menengah - bawah di Surabaya adalah faktor harga dan faktor lokasi.

2. Faktor fisik bangunan, fasilitas, lingkungan dan promosi terbukti tidak berpengaruh terhadap minat calon pembeli apartemen menengah - bawah di Surabaya.

6. DAFTAR PUSTAKA

Arikunto, S. (2006). Prosedur Penelitian Suatu Pendekatan Praktik. Jakarta: Rineka Cipta. 
Cahyani P. Diah, Ilhamdaniah, \& Indra K. D. N. (2012). "Preferensi Konsumen Apartemen di Kota Bandung." Prosiding Temu IImiah IPLBI 2012, 41-44.

Colliers International Indonesia. (2017). "Colliers half year report: Surabaya apartment H2 2016." <http://www.colliers.com> (February 18, 2017)

Dewri, L. V., Amin, M. M., Sen, M. S., \& Faridi, R. (2012). "A Comprehensive Study on The Real Estate Sector of Bangladesh." Real Estate and Housing Association of Bangladesh, 1-83.

Islam, M. S. (2012). "Factors Determining The Real Estate Company's Performance in Bangladesh: Evidence from Adept Consultants Ltd. Company." Internship Report, Independent University of Bangladesh, Bangladesh, <http://www.sb.iub.edu.bd/internship/autmn2012/0830063.pdf>

Kamal, M., \& Pramanik, S. A. K. (2015). “Customers' Intention towards Purchasing Apartment in Dhaka City, Bangladesh: Offering an Alternative Buying Intention Model." European Journal of Business and Management, Vol.7, No.35.

Kamal, M., \& Pramanik, S. A. K. (2015). "Factors Affecting Customers to Buy Apartments in Dhaka City." Daffodil Intemational University Journal of Business and Economics, 9 (2), 37-49.

Khoiruddin, M. (2010). Trik Membeli Rumah dan Apartemen untuk Hunian dan Investasi. Jakarta: Gramedia Pustaka Utama

Kinnear, T. \& Taylor, J. (2003). Riset Pemasaran. Jakarta: Erlangga.

Kotler, P. \& Keller, K. L. (2009). Manajemen Pemasaran. Jakarta: PT. Indeks.

Manivannan, P., \& Somasundaram, R. (2014). "Purchase of Residential Flats - Factors Influencing the Decision of Buyers in Selected Cities in Tamil Nadu." International Research Journal of Business and Management, Vol.7, 67-73.

Mollah, M. M. H., Haque, I., \& Pasha, S. H. A. (2009). "Factors Influencing Apartment Buying Decision: An Analysis of Company and Customer." Southeast University Joumal of Business Studies, Vol.2, 109-117.

Savitri, E., Ignatius, M., Budihardjo, A., Anwar, I., Rahwidyasa, V. (2007). Indonesian Apartment: Design Concept Lifestyle. Jakarta: PT. Griya Asri Prima

Widarti, P. (2016). "Apartemen Surabaya 2017, Banyak Proyek Baru Segmen Menengah," <http://surabaya.bisnis.com> (December 2, 2017). 